\title{
Bat diversity along an altitudinal gradient in the Itabapoana drainage basin, Espírito Santo state, Brazil
}

\author{
Vinicius Chagas Lopes ${ }^{1}$ \\ Rodrigo Lemes Martins ${ }^{2}$ \\ Átilla Colombo Ferreguetti ${ }^{3 *}$ \\ Sérgio Barbiero Lage ${ }^{1}$ \\ Rodrigo da Silva Cipriano ${ }^{1}$ \\ Kauê Freire de Paula ${ }^{1}$ \\ ${ }^{1}$ Associação Educacional de Vitória, Vitória - ES, Brasil \\ ${ }^{2}$ Universidade Federal do Rio de Janeiro, Rio de Janeiro - RJ, Brasil \\ ${ }^{3}$ Universidade do Estado do Rio de Janeiro \\ Núcleo de Pesquisas em Ecologia e Desenvolvimento Sócio-Ambiental de Macaé \\ Av. São José do Barreto, 764, CEP 27965-045, Macaé - RJ, Brasil \\ * Corresponding author \\ atilla.ferreguetti@gmail.com
}

Submetido em 23/06/2017

Aceito para publicação em 27/09/2017

\section{Resumo}

Diversidade de morcegos ao longo do gradiente altitudinal na bacia do rio Itabapoana, Espírito Santo, Brasil. Entre os mamíferos que ocorrem ao longo de todo gradiente altitudinal em montanhas no sudeste do Brasil (i.e. Mata Atlântica), os morcegos podem ser um excelente modelo de análise, porque são abundantes e apresentam todas as guildas. Nas cadeias de montanhas ao redor do mundo, a comunidade de morcegos pode apresentar dois padrões de riqueza e diversidade de espécies: 1) declínio progressivo na riqueza e diversidade de espécies à medida que a altitude aumenta; ou 2) um pico de riqueza e diversidade no nível altitudinal intermediário. Nesse contexto, o presente estudo teve como objetivo realizar um levantamento das espécies de morcegos ocorrentes nos fragmentos localizados na bacia do rio Itabapoana verificando a influência do gradiente altitudinal nas taxas de capturas dos morcegos. Para a captura dos morcegos, utilizamos redes de neblina, armadas no nível do solo, totalizando um esforço amostral de $1.500 \mathrm{~m}^{2} /$ ha para cada localidade. A região do rio Itabapoana apresentou uma elevada riqueza de espécies de morcegos (26 espécies), abrigando $44 \%$ das espécies já registradas no Espírito Santo. Nosso estudo mostrou que existe uma variação nas taxas de captura de morcegos e riqueza de espécies, com uma reposição de algumas espécies, ao longo do gradiente altitudinal na região do rio Itabapoana. As mudanças na heterogeneidade do habitat ao longo desse gradiente são provavelmente um dos fatores ecológicos fortes que afetam esses parâmetros. Além disso, os dados desse estudo permitem a expansão do conhecimento das espécies de morcegos que ocorrem na região do Itabapoana. A diversidade de espécies encontrada, juntamente com a ocorrência de espécies raras, destaca a importância da região para a conservação ajudando a entender os padrões de distribuição das espécies.

Palavras-chave: Altitude; Chiroptera; Diversidade; Levantamento; Mata Atlântica 


\section{Abstract}

Among all the mammal species that occur along every montane altitudinal gradient in southeastern Brazil (i.e. Atlantic Forest), bats are an excellent model for analysis, because they are abundant, and all trophic guilds are represented within the taxon. In mountain chains around the world, bat communities may present two patterns of species richness and diversity: 1) progressive decline in species richness and diversity as the altitude increase or 2) a peak of richness and diversity in intermediate altitudinal level. In this context, we aimed to survey the bat species occurring in the Atlantic Forest remnants located in the Itabapoana drainage basin (IDB) and to verify how altitude affects bat capture rates. We used mist-nets to capture bats, which were set up at ground level, totaling $1,500 \mathrm{~m}^{2} / \mathrm{ha}$ of sampling effort for each location. The IDB has a diverse assemblage of species (26 species), representing 44\% of the bat species of Espírito Santo. Our study showed that there is variation in bat capture rates and species richness, with a turnover of some species along the altitudinal gradient in the IDB. Changes in habitat heterogeneity along the elevation gradient are probably one of the strong ecological factors affecting these assemblage parameters. Furthermore, the data from this study allows the expansion of knowledge of the bat species occurring in the region of the IDB. The diversity of species found, together with the occurrence of rare, threatened, and data deficient species highlights the importance of the region for conservation to understand the species distribution patterns.

Key words: Altitude; Atlantic Forest; Chiroptera; Diversity; Inventory

\section{Introduction}

There are about 300 species of mammals occurring in the Atlantic Forest, of which $30 \%$ are endemic (PAGLIA et al., 2012). Currently in Brazil there are 178 species of bats with known occurrence (Mammalia: Chiroptera), with 113 species occurring in the Atlantic Forest (NOGUEIRA et al., 2014). Bats play an important role in maintaining ecological processes by participating in pollination (SILVA; PERACCHI, 1995; MARTINS; GRIBEL, 2007), seed dispersal (LOPEZ; VAUGHAN, 2004; SATO et al., 2008) and population control of many insect species (AGUIAR; ANTONINI, 2008). However, despite the high diversity of bats in the Atlantic Forest and their ecological importance, data on the biology and ecology of these animals remain insufficiently known (BERNARD et al., 2011). Many Brazilian bat studies took place in the Atlantic Forest (BERNARD et al., 2011). The states of Rio de Janeiro and Espírito Santo (ES) are currently listed as harboring the greatest diversity of species in the Atlantic Forest, however, ES still has geographical gaps (ESBÉRARD; BERGALLO, 2005; PERACCHI; NOGUEIRA, 2008; MENDES et al., 2010).
The decrease of floristic and faunistic diversity with increasing altitude is one of the most documented biogeographic characteristics in the literature around the globe (RAHBEK, 1997; GRYTNES, 2003; McCAIN; GRYTNES, 2010; CARVALHO, 2015).

The Itabapoana drainage basin, located in southeastern Brazil on the border between Espírito Santo, Rio de Janeiro, and Minas Gerais, is known to be a suitable area for a high species diversity (MENDES et al., 2010). This is in part because the area has been sub-sampled (MENDES et al., 2010) and it was reported that the area has a high altitude variation with different vegetation types, which occupy from coastal plains to points that reach $2,800 \mathrm{~m}$ altitude (IBDF/ FBCN, 1981). Thus, considering that the Itabapoana drainage basin was considered a priority for the inventory of bats (MENDES et al., 2010), we aimed to fill an existing knowledge gap, presenting here a species composition throughout this river drainage, and assessing the influence of an altitudinal gradient in species capture rate. 


\section{Material and Methods}

\section{Study area}

The drainage basin of the Itabapoana (IDB) is located in southeastern Brazil, covering the states of Espírito Santo, Minas Gerais, and Rio de Janeiro. The IDB estuary is located between the cities of President Kennedy, ES and São Francisco do Itabapoana, RJ. The IDB drains an area of $4,875 \mathrm{~km}^{2}$, and much of this area is located in Espírito Santo, which drains an area of $2,955 \mathrm{~km}^{2}$ (LANI et al., 2008). Samples were obtained in 26 sampling sites along the northern portion of the IDB, with a minimum distance of $1 \mathrm{~km}$ between sites. Sampling included the municipalities of Presidente

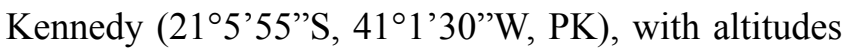
between 14 and $34 \mathrm{~m}$ above sea level, Mimoso do Sul

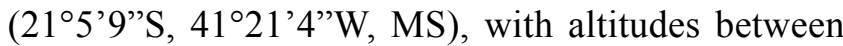
13 and $46 \mathrm{~m}$, São José dos Calçados $\left(21^{\circ} 0^{\prime} 28^{\prime}\right.$ 'S, 41 $\left.41^{\prime} 39^{\prime \prime} \mathrm{W}, \mathrm{SJC}\right)$, with altitudes between 444 and 630 m, Guaçuí (2048'14”S, 41³9'48”W, G), with altitudes between 567 and $880 \mathrm{~m}$, and Dores do Rio

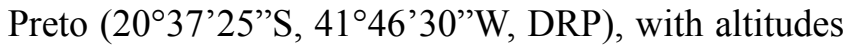
between 725 and $1422 \mathrm{~m}$ (Figure 1).

Originally the surrounding of the IDB was covered by the Atlantic forest, of which only small fragments remain, mainly in the higher altitude (INPE; SOS MATA ATLÂNTICA, 2002). The IDB climate has a higher occurrence of rainfall during the months of November to February, and a drier period extending from July to September. The average temperature in the warmer months approaches $24^{\circ} \mathrm{C}$, and in the colder months it is roughly $18^{\circ} \mathrm{C}$. Relative humidity remains close to $80 \%$ throughout the year (FEITOZA, 1979).

FIGURE 1: Sampling sites for the survey of bat species Itabapoana drainage basin in the Espírito Santo state, Brazil.

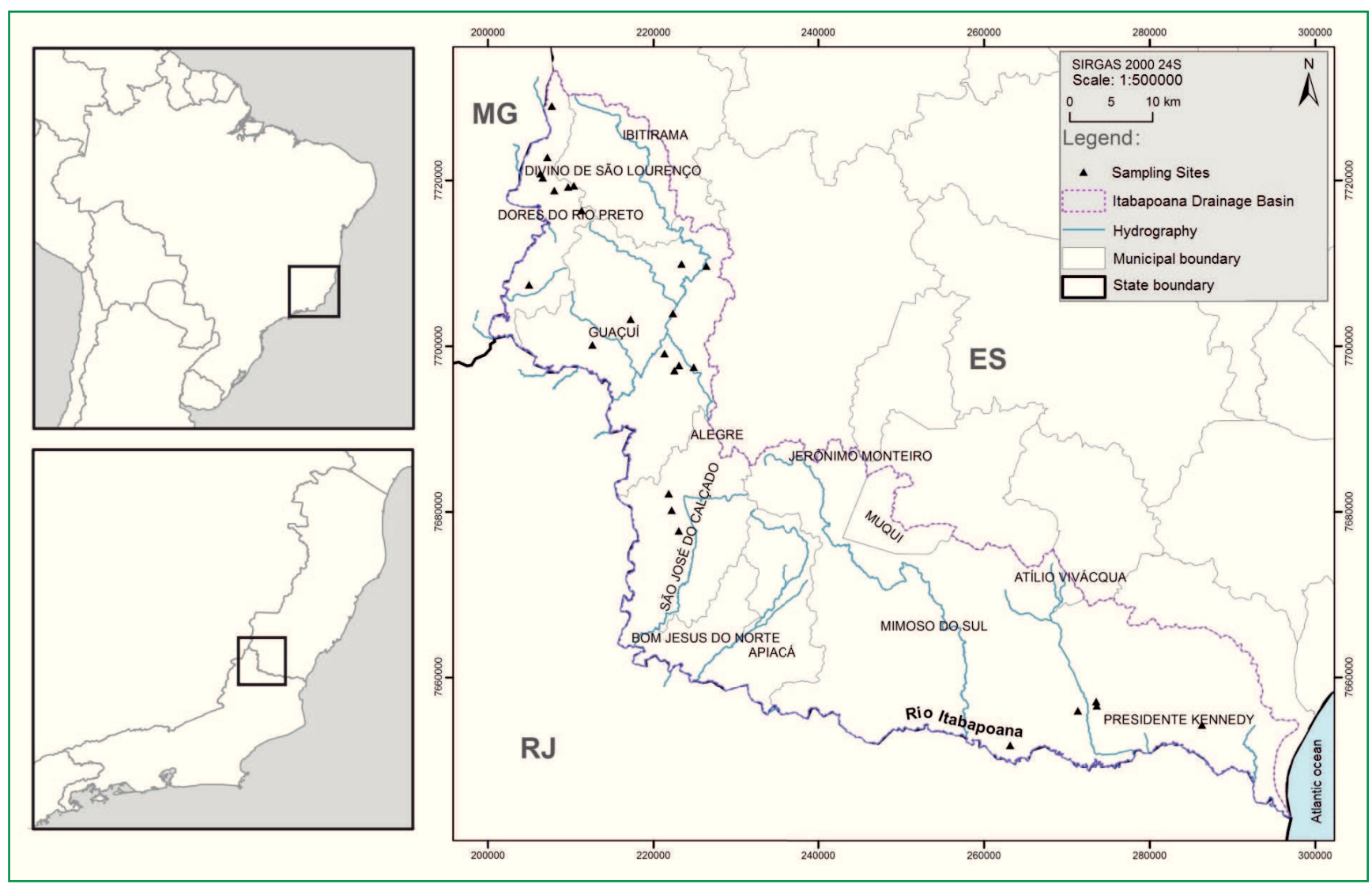




\section{Data collection}

All 26 sampling sites were sampled between 2010 and 2012 during the rainy season (Table 1). Bats were captured using mist nets and between 25 to 30 bats were captured each night. The mist nets ranged from $7 \times 2.5$ $\mathrm{m}$ to $12 \times 2.5 \mathrm{~m}$. They were opened during the first six hours after sunset for five nights, totaling $30 \mathrm{~h}$ per site sampled. The mist nets were set at ground level, and were arranged to represent all environments available in an area of up to $250 \mathrm{~m}$ in diameter, including streams, fruit trees, trails and clearings located in the interior or on the edge of forest fragments. We avoided opening nets in the same place in consecutive days. All captures were made during the waning moon phase. Our sampling effort was calculated following Straube and Bianconi (2014), by multiplying the area of each net $\left(\mathrm{m}^{2}\right)$ by the total number of nets opened each night and the total number of working hours. We carried out a total of five sampling nights, which resulted in a total capture effort of $7,500 \mathrm{~m}^{2} / \mathrm{ha}$.

Captured bats were identified, measured, and released, except for one individual of each species by sampling night. These were deposited as voucher specimens in the mammal collections in Ecology and Environmental Development Macaé, Federal University of Rio de Janeiro - Campus Macaé

TABLE 1: Characteristics of each sampling site for the survey of bat species in the Itabapoana drainage basin in Espírito Santo, Brazil. The sampling sites are organized by sampled municipalities.

\begin{tabular}{|c|c|c|}
\hline Sampling site & Altitude (m) & Sampling effort $\left(\mathrm{m}^{2} / \mathrm{ha}\right)$ \\
\hline \multicolumn{3}{|l|}{ Dores do Rio Preto } \\
\hline Site 01 & 1350 & 300 \\
\hline Site 02 & 930 & 300 \\
\hline Site 03 & 810 & 300 \\
\hline Site 04 & 725 & 300 \\
\hline Site 05 & 1422 & 300 \\
\hline \multicolumn{3}{|l|}{ Guaçuí } \\
\hline Site 06 & 880 & 300 \\
\hline Site 07 & 750 & 300 \\
\hline Site 08 & 640 & 300 \\
\hline Site 09 & 567 & 300 \\
\hline Site 10 & 615 & 300 \\
\hline \multicolumn{3}{|l|}{ Mimoso do Sul } \\
\hline Site 11 & 35 & 300 \\
\hline Site 12 & 13 & 400 \\
\hline Site 13 & 20 & 400 \\
\hline Site 14 & 25 & 400 \\
\hline \multicolumn{3}{|l|}{ Presidente Kennedy } \\
\hline Site 15 & 30 & 300 \\
\hline Site 16 & 20 & 200 \\
\hline Site 17 & 14 & 200 \\
\hline Site 18 & 34 & 300 \\
\hline Site 19 & 25 & 250 \\
\hline Site 20 & 30 & 250 \\
\hline \multicolumn{3}{|l|}{ São José dos Calçados } \\
\hline Site 21 & 450 & 300 \\
\hline Site 22 & 444 & 200 \\
\hline Site 23 & 600 & 200 \\
\hline Site 24 & 630 & 200 \\
\hline Site 25 & 550 & 300 \\
\hline Site 26 & 500 & 300 \\
\hline
\end{tabular}


(Appendix 1). The study was conducted under the license 4726-1 SISBIO. Individuals were identified according to Laval (1973), Vizotto and Taddei (1973), Gregorin and Taddei (2002), and other references (TADDEI et al., 1998; BERNARDI et al., 2007; ARAÚJO; LANGGUTH, 2010). We used Paglia et al. (2012) for the nomenclature and taxonomic order of the species. Captures, management and procedures followed the guidelines of the American Society of Mammalogists (SIKES; GANNON, 2011).

\section{Data analysis}

The sample sufficiency was checked from the accumulative number of species in the number of nights sampled using the Mao Tau method (COLWELL et al., 2004). The calculation of the estimated richness was obtained using two richness estimators: a first order jackknife, which allows a reliable estimate of the richness even in low sampling and first order Chao, which is based on the number of individuals of rare species.

To present the variation in individual capture rate of different bat species along the altitudinal gradient, we calculate the relative capture rate of each species by altitude (RIEC - Relative Interspecific Elevational Index, BONVICINO et al., 1997). RIEC is calculated by the formula (nei/NEi) x 100, where nei is the number of specimens of a species in a given altitude (i), and NEi is the total number of species obtained at the same altitude (i). The RIEC values calculated for the species at each altitude are presented graphically ordering the species based on higher values for altitude range, considering: bats captured in areas above $1,000 \mathrm{~m}$ altitude, between 800 and $1,000 \mathrm{~m}$, between 600 and $800 \mathrm{~m}$, between 400 and $600 \mathrm{~m}$, and between 100 and $400 \mathrm{~m}$.

Considering all samplings, species with capture rates greater than $10 \%$ were evaluated with respect to the variation of RIEC values at each sampling site (dependent variable) as a function of altitude (predictor variable). The RIEC values of each sampling site were transformed using an arcsine function and after verifying for normality and homoscedasticity (respectively by
Shapiro and Wilk test and Levene), evaluations were made using simple regression. The RIEC values of each species in each locality were also used to check for the occurrence of correlations between species. Statistical analyzes were made through the software STATISTICA (data analysis software system) version 7.

\section{Results}

We captured 581 individuals of 26 species of bats, with 19 species of Phyllostomidae, four species of Vespertilionidae, two species of Molossidae and one of Noctilionidae (Table 2). Two bat species had higher capture rate than 10\%, Sturnira lilium (26.5\%) and Carollia perspicillata (25.5\%). The species $C$. perspicillata showed higher percentage of capture in most of the sampled municipalities (Guaçuí $=27.6 \%$; Mimoso do Sul $=41.1 \%$; Presidente Kennedy $=54.5 \%$ and São José do Calçado $=36.4 \%$ ) and S. lilium was the dominant species in the municipality of Dores do Rio Preto $(53.8 \%)$. There was a rapid increase in captured species at the beginning of the sample (first nine nights), with occasional additions to the end of sampling. Thus, for about $33 \%$ of the sampled nights, it was possible to obtain $92.6 \%$ of the richness found in this study. Using the species-nights rarefaction curve by Mao Tau method tended to stabilize in 27 species. The Chao estimator first order estimated 28 species for the area and the Jackknife estimated 30 species (Figure 2).

It was possible to verify differences in species capture rate between different altitudes with higher richness in the range between 800 and $1,000 \mathrm{~m}$ elevation (Figure 3). There is also a variation in the capture rate for the species S. lilium, that was the dominant species in areas of high altitude above $600 \mathrm{~m}$, with capture rate peaking in the altitudinal quota over $1000 \mathrm{~m}$, with a gradual reduction in lower quotas altitude (800-1,000 and 600-800 m). Carollia perspicillata was the dominant species in the lower altitude ranges (less than $600 \mathrm{~m}$ ), except for the restinga ecosystems, where Artibeus lituratus was the dominant species caught (Figure 3 ). 
TABLE 2: List of species sampled with the respective number of individuals in the Itabapoana drainage basin region in the sampled municipalities: Dores do Rio Preto (DRP), Guaçuí (G), Mimoso do Sul (MS), Presidente Kennedy (PK), São José dos Calçados (SJC), Espírito Santo state, Brazil. The sampling period was between 2010 and 2012.

\begin{tabular}{llllllll}
\hline \multirow{2}{*}{ Taxon } & \multicolumn{4}{c}{ Sampled sites } \\
\cline { 2 - 6 } & DRP & G & SJC & MS & PK & Total \\
\hline
\end{tabular}

\section{Phyllostomidae}

Carolliinae

Carollia perspicillata (Linnaeus, 1758)

Desmondotinae

Desmodus rotundus (É. Geoffroy, 1810)

Glossophaginae

Anoura caudifer (É. Geoffroy, 1818)

Anoura geoffroyi Gray, 1838

Glossophaga soricina (Pallas, 1766)

Phyllostominae

Chrotopterus auritus (Peters, 1856)

Lonchorhina aurita Tomes, 1863

Micronycteris hirsuta (Peters, 1869)

Micronycteris microtis Miller, 1898

Micronycteris minuta (Gervais, 1856)

Trachops cirrhosus (Spix, 1823)

Stenodermatinae

Artibeus fimbriatus Gray, 1838

Artibeus lituratus (Olfers, 1818)

Artibeus obscurus (Schinz, 1821)

Artibeus cinereus (Gervais, 1855)

Chiroderma doriae Thomas, 1891

Platyrrhinus lineatus (É. Geofroy, 1810)

Platyrrhinus recifinus (Thomas, 1901)

$$
21
$$

29

32

39

30

151

4

10

4

4

0

22

$$
5
$$

2

1

2

0

0

7

0

0

0

0

14

1

\section{0}

0

0

1

0

0

$\begin{array}{cccccc}7 & 7 & 0 & 0 & 2 & 16 \\ 13 & 14 & 9 & 5 & 6 & 47 \\ 0 & 0 & 0 & 1 & 0 & 1 \\ 0 & 2 & 1 & 1 & 1 & 5 \\ 0 & 3 & 0 & 0 & 0 & 3 \\ 1 & 1 & 3 & 0 & 0 & 5 \\ 2 & 7 & 1 & 2 & 7 & 19 \\ 83 & 26 & 15 & 32 & 6 & 162\end{array}$

\section{Noctilionidae}

\begin{tabular}{lcccccc}
\hline Noctilio leporinus (Linnaeus, 1758) & 0 & 0 & 0 & 0 & 1 & 1 \\
\hline Molossidae & & & & & & \\
\hline Molossus rufus E. Geoffroy, 1805 & 0 & 0 & 0 & 0 & 1 & 1 \\
Molossus molossus (Pallas, 1766) & 0 & 0 & 0 & 0 & 1 & 1 \\
\hline Vespertilionidae & & & & & & \\
\hline Myotis nigricans (Schinz, 1821) & 5 & 0 & 1 & 2 & 1 & 9 \\
Myotis riparius Handley, 1960 & 0 & 1 & 0 & 0 & 0 & 1 \\
Myotis ruber (É. Geoffroy, 1806) & 5 & 1 & 0 & 0 & 0 & 6 \\
Eptesicus brasiliensis (Desmarest, 1819) & 1 & 0 & 2 & 0 & 1 & 4 \\
\hline Total & 151 & 105 & 88 & 95 & 55 & 581 \\
\hline Richness & 14 & 14 & 12 & 9 & 11 & 26 \\
\hline
\end{tabular}


FIGURE 2: Curves of bat species accumulation captured in Itabapoana drainage basin, Espirito Santo state, Brazil. Estimated richness $($ Mao Tao) ( $\mathbf{\Delta})$, richness with estimator Chao $1(\bullet)$ and richness with the estimator Jackknife $1(\boldsymbol{\bullet})$. The sampling period was between 2010 and 2012 .

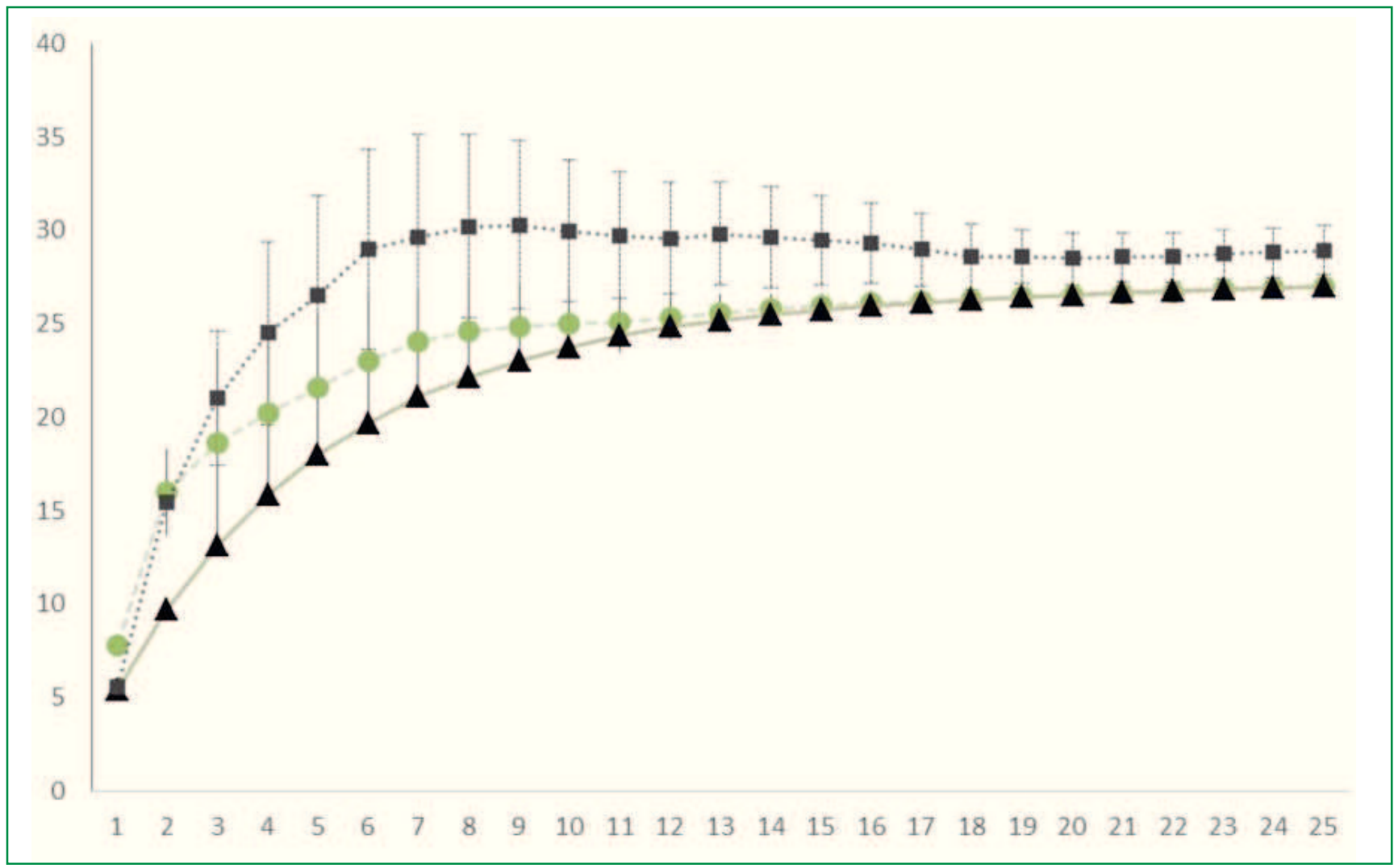

We recorded a small number of species restricted to specific altitude classes, such as: Anoura geoffroyi, Myotis nigricans, Micronycteris microtis and Myotis riparius, at altitudes above $800 \mathrm{~m}$; Micronycteris hirsuta, Micronycteris minuta, Chiroderma doriae and Chrotopterus auritus, at altitudes between 400 and $800 \mathrm{~m}$; Artibeus obscurus and Thrachops cirrhosus, at altitudes up to $400 \mathrm{~m}$. None of the above species obtained RIEC more than five percent of total collections by altitude. We found a significant relationship between the number of captured individuals of $C$. perspicillata and altitude $(\mathrm{t}=-3.02, \mathrm{df}=21, \mathrm{p}<0.01)$. The number of captures of $C$. perspicillata was negatively correlated with the relative captures of $S$. $\operatorname{lilium}(\mathrm{t}=-3.24, \mathrm{~N}=23$, $\mathrm{p}<0.01)$ which showed an increasing trend as a function of altitude $(\mathrm{t}=1.92 ; \mathrm{df}=21 ; \mathrm{p}=0.06)$ (Figure 4$)$. 
FIGURE 3: Graph showing the relative capture rate of each species by altitude (RIEC) of the drainage basin of Itabapoana - Espírito Santo state. The sampling period was between 2010 and 2012.

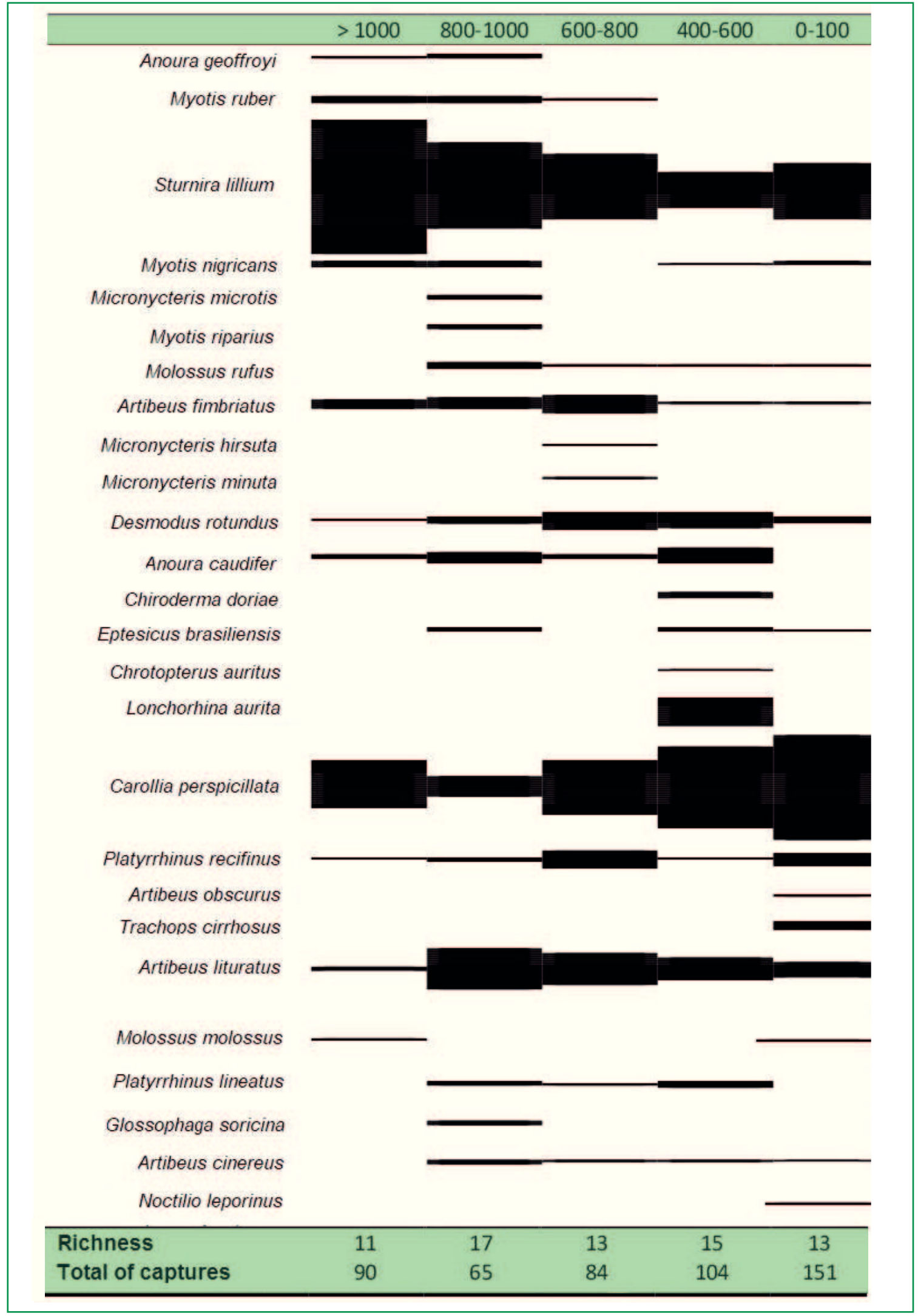


FIGURE 4: Relative capture rate per sample site (RIEC -. Bonvicino et al 1997) of Carollia perspicillata (o - continuous line) and Sturnira lilium (+ - dashed line) depending on the altitude in Espírito Santo, Brazil. The sampling period was between 2010 and 2012.

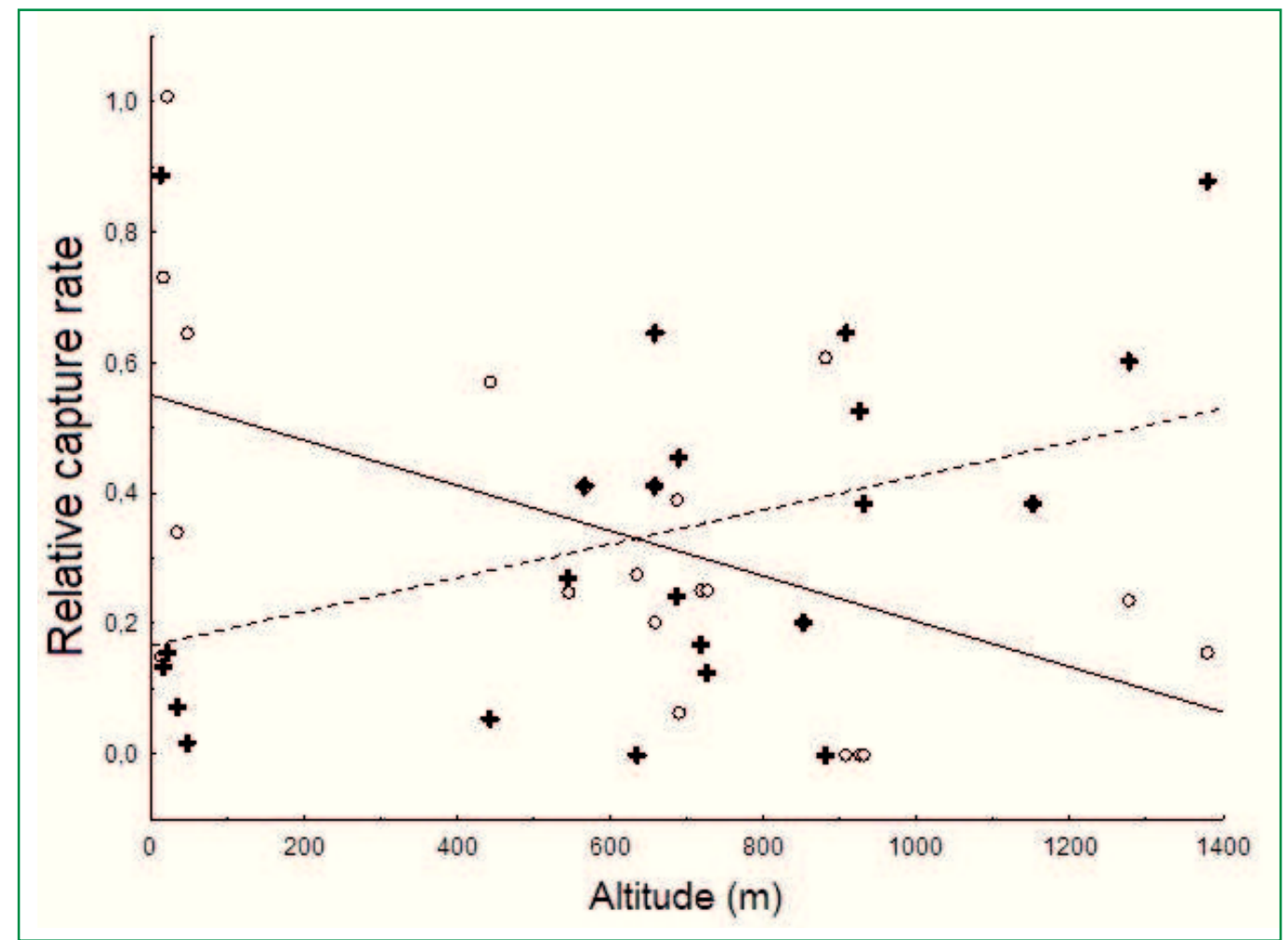

\section{Discussion}

The effort performed in the present study was sufficient to sample almost $91.8 \%$ of the estimated bats richness of the IDB. Compared to other studies in the Brazilian Atlantic forest, richness was high (e.g, BIANCONI et al., 2004; PEDRO et al., 2014). This high richness seems to be related to the high-altitudinal variation found in the sampled areas. Moreover, Stevens (2013) pointed out that latitude and altitude would be the main factors affecting the richness of Atlantic Forest bat assemblages. Although our capture effort is below that recommended by Bergallo et al. (2003), who suggested that an effort between 750 and 1,000 captures would be able to adequately evaluate assemblages of bats from the Atlantic Forest, we found a high richness considering that we had 581 captures. However, if we compared our results to studies with a higher sampling effort, richness can be considerably lower (ESBÉRARD, 2003).
We observed that the richness along the altitudinal gradient decreases markedly after $1,000 \mathrm{~m}$. Carvalho (2015) observed similar results for phyllostomid bats in the Atlantic Forest, with higher hematophagous abundance and lower abundance of frugivores. This lower abundance and richness of bats is also observed in other biomes, such as the east of the Andes (McCAIN; GRYTNES, 2010; CISNEROS et al., 2014). This pattern in the Atlantic Forest and other locations it is because these higher altitude locations present extreme environmental features (e.g. the slopes receive higher amount of rainfall, and the elevational profile begins at low altitudes and there is no plateau at altitudes between 1,000 and 2,000 m). Graham et al. (2014) argued that the variation in richness and diversity along an altitudinal gradient is strongly linked to the natural history and environmental characteristics of each chain of mountains, and for bats, a pattern of decline in richness is observed with higher altitudes, showing a richness peak at mid-altitudes (McCAIN; GRYTNES, 2010; CARVALHO, 2015). 
The richness recorded in the present study represents $14.6 \%$ of the 178 species of bats registered for Brazil (NOGUEIRA et al., 2014), 23\% of those recorded for the Atlantic Forest (PAGLIA et al., 2012), and 44\% of those recorded for Espírito Santo (PERACCHI et al., 2011). The predominance of phyllostomid bats is probably due to the capture method used, since the use of mist nets at ground level favors higher capture rates of this family, particularly fruit bats (SIPINSKI; REIS, 1995; PEDRO; TADDEI, 1997; KALKO, 1998; PORTFORS et al., 2000). In addition, this study confirms the record for two species in Espírito Santo, Micronycteris microtis (PERACCHI et al., 2011) and Chiroderma doriae (SCABELLO et al., 2009), and expands the distribution of Myotis riparius to another vegetation type, and municipality (Guaçuí).

In this study, the records of Myotis ruber occurred mostly in the municipality of Dores do Rio Preto $(\mathrm{N}=5)$ above $850 \mathrm{~m}$, and we recorded one individual in the municipality of Guaçuí at $650 \mathrm{~m}$. According to Weber et al. (2010), most records of this species come from Atlantic Forest sites at high altitudes. However, the same authors concluded that a combination of marked seasonality in temperature and high precipitation of a period of the year, and not altitude, are important factors influencing the occurrence of this species.

The dominance of Carollia perspicillata and Artibeus lituratus is commonly found in bat surveys in the Atlantic Forest (ESBÉRARD, 2003; FARIA, 2006; DIAS; PERACCHI, 2008; VIEIRA et al., 2010), and in this study $C$. perspicillata obtained dominance in most sampled municipalities and altitudes lower than $600 \mathrm{~m}$. The dominance of Sturnira lilium at altitudes higher than $600 \mathrm{~m}$ corroborates other studies that have also worked in high altitudes of the Atlantic Forest (FALCÃO et al., 2003; NOBRE et al., 2009; LUZ et al., 2013). A study by Nobre et al. (2009) suggests that the high diversity of Solanaceae plants influences the dominance of S. lilium, given that this species presents a feeding preference for fruits of this family (MULLER; REIS, 1992; PASSOS et al., 2003). However, in a study by Mello et al. (2008) evaluating the availability of Solanaceae fruits and temperature of the air, it was found that the air temperature has greater influence on the distribution of this species in high altitude regions.

Our study showed that there is a variation in bat capture rates and species richness, with a turnover of some species along the altitudinal gradient in the region of Itabapoana drainage basin. Changes in habitat heterogeneity along the elevation gradient are probably one of the strong ecological factors affecting these assemblage parameters. Furthermore, the data from this study allows the expansion of knowledge of the bat species occurring in the region of the IDB. The diversity of species found, together with the occurrence of rare, threatened, and data deficient species highlights the importance of the region for conservation to understand the species distribution patterns.

\section{Acknowledgements}

At Renata Costa Carvalho, for the support in the field. To Pablo Rodrigues Gonçalves the important corrections to the final text. Owners of forest fragments studied. At Pousada Vovôzinho for supporting the food and lodging. In the NGO IDEAWILD the material used in the catch. IPEMA to the financing of campaigns in South Mimoso and Presidente Kennedy through the PDA no 102 and no 120 FUNBIO projects.

\section{References}

AGUIAR, L. M. S.; ANTONINI, Y. Diet of two sympatric insectivores bats (Chiroptera: Vespertilionidae) in the Cerrado of Central Brazil. Revista Brasileira de Zoologia, Curitiba, v. 25, p. 28-31, 2008.

ARAÚJO, P.; LANGGUTH, A. Caracteres distintivos das quatro espécies de grandes Artibeus (Phyllostomidae) de Paraíba e Pernambuco, Brasil. Chiroptera Neotropical, Brasília, v. 16, p. 715-722, 2010.

BERGALLO, H. G.; ESBÉRARD, C. E. L.; MELLO, M. A. R.; LINS, V.; MANGOLIN, R.; BAPTISTA, M. Bat species richness in Atlantic Forest: What is the minimum sampling effort? Biotropica, Malden, v. 35, p. 278-288, 2003.

BERNARD, E.; AGUIAR, L. M. S.; MACHADO, R. B. Discovering the Brazilian bat fauna: a task for two centuries? Mammalian Review, Southampton, v. 41, p. 23-39, 2011.

BERNARDI, I. P.; PULCHÉRIO-LEITE, A.; MIRANDA, J. M.; PASSOS, F. C. Ampliação da distribuição de Molossops neglectus Williams \& Genoways (Chiroptera, Molossidae) para o Sul da 
América do Sul. Revista Brasileira de Zoologia, Curitiba, v. 24, p. 505-507, 2007.

BIANCONI, G. V.; MIKICH, S. B.; PEDRO, W. A. Diversidade de morcegos (Mammalia, Chiroptera) em remanescentes florestais do município de Fênix, noroeste do Paraná, Brasil. Revista Brasileira de Zoologia, Curitiba, v. 21, p. 943-954, 2004.

BONVICINO, C. R.; LANGGUTH, A.; LINDBERGH, S. M.; DE PAULA, A. C. An elevational gradient study of small mammals at Caparaó National Park, Southeastern Brazil. Mammalia, Paris, v. 61, p. 547-560, 1997.

CARVALHO, W. D. Influência da altitude na história de vida de morcegos Phyllostomidae (Chiroptera, Mammalia) na Floresta Atlântica. 2015. 87 f. Tese (Doutorado em Biologia Animal) Universidade Federal Rural do Rio de Janeiro, Rio de Janeiro. 2015.

CISNEROS, L. M.; BURGIO, K. R.; DREISS, L. M.; KLINGBEIL, B. T.; PATterson, B. D.; PRESley, S. J.; WILliG, M. R. Multiple dimensions of bat biodiversity along an extensive tropical elevational gradient. Journal of Animal Ecology, London, v. 83, p. 1124-1136, 2014.

COLWELL, R. K.; MAO, C. X.; CHANG, J. Interpolating, extrapolating, and comparing incidence-based species accumulation curves. Ecology, New York, v. 85, p. 2717-2727, 2004.

DIAS, D.; PERACCHI, A. L. Quirópteros da Reserva Biológica do Tinguá, estado do Rio de Janeiro, sudeste do Brasil (Mammalia: Chiroptera). Revista Brasileira de Zoologia, Curitiba, v. 2, p. 333369, 2008.

ESBÉRARD, C. E. L. Diversidade de morcegos em área de Mata Atlântica regenerada no sudeste do Brasil. Revista Brasileira de Zoociências, Juiz de Fora, v. 5, p. 23-45, 2003.

ESBÉRARD, C. E. L.; BERGALLO, H. G. Research on bats in the state of Rio de Janeiro, Southeastern Brazil. Mastozoologia Neotropical, Mendoza, v. 12, p. 237-246, 2005.

FALCÃO, F. de C.; REBÊLO, V. F.; TALAMONI, S. A. Structure of bat assemblage (Mammalia, Chiroptera) in Serra do Caraça Reserve, Southeast Brazil. Revista Brasileira de Zoologia, Curitiba, v. 20, p. 347-350, 2003.

FARIA, D. Phyllostomid bats of a fragmented landscape in the north-eastern Atlantic Forest, Brazil. Journal of Tropical Ecology, Winchelsea v. 22, p. 531-542, 2006.

FEITOZA, L. R. Estimativas das temperaturas médias mensais e anual no estado do Espirito Santo. Revista do Centro de Ciências Rurais, Santa Maria, v. 9, p. 271-291, 1979.

GRAHAM, C. H.; CARNAVAL, A. C.; CADENA, C. D.; ZAMUDIO, K. E.; ROBERTS, T. E.; PARRA, J. L.; MACCAIN, C. M.; BOWIE, R. C. K.; MORITZ, C.; BAINES, S. B.; SCHNEIDER, C. J.; VANDERWAL, J.; RAHBEK, C.; KOZAK, K. H.; SANDERS, N. J. The origin and maintenance of montane diversity: integrating evolutionary and ecological processes. Ecography, Lund, v. 37, p. 711-719, 2014.

GREGORIN, R.; TADDEI, V. A. Chave artificial para a identificação de molossídeos brasileiros (Mammalia, Chiroptera). Mastozoología Neotropical, Mendoza, v. 9, p. 13-32, 2002.

GRYTNES, J. A. Species-richness patterns of vascular plants along seven altitudinal transects in Norway. Ecography, Lund, v. 26, n. 3, p. 291-300, 2003.
IBDF/FBCN. Plano de manejo do Parque Nacional do Caparaó. Brasília: IBDF/FBCN, 1981. 139 p.

INPE; FUNDAÇÃO SOS MATA ATLÂNTICA. Atlas dos remanescentes florestais de Mata Atlântica - Período: 19952000. Fundação SOS Mata Atlântica, São Paulo, 2002. 45 p.

KALKO, E. K. V. Organization and diversity of tropical bat communities through space and time. Zoology, Jena, v. 101, p. 281-297, 1998.

LANI, J. L.; RESENDE, M.; REZENDE, S. B. de.; FEITOZA, L. R. Atlas de ecossistemas do Espírito Santo. Vitória: SEMA/ Viçosa: UFV, 2008. 504 p.

LAVAL, R. K. A revision of the neotropical bats of the genus Myotis. Science Bulletin Natural History Museum Los Angeles County, Los Angeles, v. 15, p. 1-53, 1973.

LOPEZ, J. E.; VAUGHAN, C. Observations on the role of frugivorous bats as seed dispersers in Costa Rican Secondary humid forests. Acta Chiropterologica, Warsaw, v. 6, p. 111-119, 2004.

LUZ, J. L.; COSTA, L. M.; NOGUEIRA-JORDÃO, T. Morcegos em área de Floresta Montana, Visconde de Mauá, Resende, Rio de Janeiro. Biota Neotropica, Campinas, v. 13, p. 190-195, 2013.

MARTINS, R. L.; GRIBEL, R. Polinização de Caryo carvillosum (Aubl.) Pers. (Caryo caraceae) uma árvore emergente da Amazônica Central. Revista Brasileira de Botânica, São Paulo, v. 30, p. 37-45, 2007.

McCAIN, C. M.; GRYTNES, J. A. Elevational gradients in species richness. In: Encyclopedia of Life Sciences (ELS). Chichester: John Wiley \& Sons Ltd., 2010. p. 1-10.

MELLO, M. A. R.; KALKO, E. K. V.; SILVA, W. R. Diet and abundance of the bat Sturnira lilium (Chiroptera) in a Brazilian Montane Atlantic Forest. Journal of Mammalogy, Lawrence, v. 89, p. 485-492, 2008.

MENDES, P.; VIEIRA, T. V.; OPREA, M.; LOPES, S. R.; DITCHFIELD, A. D.; ZORTÉA, M. O conhecimento sobre morcegos (Chiroptera: Mammalia) do estado do Espírito Santo, sudeste do Brasil. Papéis Avulsos de Zoologia, São Paulo, v. 50, p. 363-373, 2010.

MULLER, M. F.; REIS, N. R. Partição de recursos alimentares ente quatro espécies de morcegos frugívoros (Chiroptera, Phyllostomidae). Revista Brasileira de Zoologia, Curitiba, v. 9, p. 345-355, 1992.

NOBRE, P. H.; RODRIGUES, A. dos S.; COSTA, I. de A.; MOREIRA, A. M. da S.; MOREIRA, H. H. Similaridade da fauna de Chiroptera (Mammalia, da Serra Negra, municípios de Rio Preto e Santa Bárbara do Monte Verde, Minas Gerais, com outras localidades da Mata Atlântica. Biota Neotropica, Campinas, v. 9, p. 51-156, 2009.

NOGUEIRA, M. R.; LIMA, I. P. de; MORATELLI, R.; CUNHA TAVARES, V. da; GREGORIN, R.; PERACCHI, A. L. Checklist of Brazilian bats, with comments on original records. Check List, Rio Claro, v. 10, p. 808-821, 2014.

PAGliA, A. P.; FONSECA, G. A. B. DA; RYLANDS, A. B.; HERRMANN, G.; AGUIAR, L. M. S.; CHIARELLO, A. G.; LEITE, Y. L. R.; COSTA, L. P.; SICILIANO, S.; KIERULFF, M. C. M.; MENDES, S. L.; TAVARES, V. da C.; MITTERMEIE, R. A.; PATTON, J. L. Lista anotada dos mamíferos do Brasil. 2. ed. Occasional Papers in Conservation Biology, n. 6. Arlington: Conservation International, 2012. 76 p. 
PASSOS, F. C.; SILVA, W. R.; PEDRO, W. A.; BONIN, M. R. Frugivoria em morcegos (Mammalia, Chiroptera) no Parque Estadual Intervales, sudeste do Brasil. Revista Brasileira de Zoologia, Curitiba, v. 20, p. 511-517, 2003.

PEDRO, W. A.; TADDEI, V. A. Taxonomic assemblage of bats from Panga Reserve, southeastern Brazil: abundance patterns and trophic relations in the Phyllostomidae (Chiroptera). Boletim do Museu de Biologia Mello Leitão, Santa Teresa, v. 6, p. 3-21, 1997. PEDRO, W. A., PASSOS, F. C.; LIM, B. K. Morcegos (Chiroptera: Mammalia) da Estação Ecológica dos Caetetus, estado de São Paulo. Chiroptera Neotropical, Brasília, v. 7: 136-140. 2014.

PERACCHI, A. L.; NOGUEIRA, M. R. Quirópteros da Mata Atlântica do sudeste do Brasil. In: PACHECO, S. M.; MARQUES, R. V.; ESBÉRARD, C. E. L. (Org.). Morcegos no Brasil: biologia, sistemática, ecologia e conservação. Porto Alegre: Armazém Digital, 2008. p. 315-336.

PERACCHI, A. L.; NOGUEIRA, M. R.; LIMA, I. P. Novos achados à lista dos quirópteros do município de Linhares, estado do Espírito Santo, sudeste do Brasil (Mammalia, Chiroptera). Chiroptera Neotropica, Brasília, v. 17, p. 34-43, 2011.

PORTFORS, C. V.; FENTON, M. B.; AGUIAR, L. M. de S. A.; BAUMGARTEN, J. E.; VONHOF, M. J. ; BOUCHARD, S.; FARIA, D. M. de; PEDRO, W. A.; RAUNTENBACH, N. I. L. ; ZORTEA, M. Bats from Fazenda Intervales southeastern Brazil - species account and comparison between different sampling methods. Revista Brasileira de Zoologia, Curitiba, v. 17, p. 533538, 2000.

RAHBEK, C. The relationship among area, elevation, and regional species richness in Neotropical birds. The American Naturalist, Chicago, v. 149, n. 5, p. 875-902, 1997.

SATO T. M.; PASSOS, F. C.; NOGUEIRA, A. C. Frugivoria de morcegos (Mammalia, Chiroptera) em Cecropia pachystachya (Urticaceae) e seus efeitos na germinação das sementes. Papéis Avulsos de Zoologia, São Paulo, v. 48, p. 19-26, 2008.

SCABELLO, M.; OLIVEIRA, L. F. de; CIPRIANO, R. da S.; CARVALHO, R. C.; DITCHFIELD, A. D.; GREGORIN, R.; MARTINS, R. L. Mammalia, Chiroptera, Phyllostomidae, Chirodermadoriae: first record for the state of Espírito Santo, Brazil, and Distribution map. CheckList, Rio Claro, v. 5, p. 539$541,2009$.
SILVA, S. S. P.; PERACCHI, A. L. Observação da visita de morcegos (Chiroptera) às flores de Pseudobombax grandiflorum (Cav.) A. Robyns. Revista Brasileira de Zoologia, Curitiba, v. 12: 859-865, 1995.

SIKES, R. S.; GANNON, W. L. Guidelines of the American Society of Mammalogists for the use of wild mammals in research. Journal of Mammalogy, Lawrence, v. 92, p. 235-253, 2011.

SIPINSKI, E. A. B.; REIS, N. R. Dados ecológicos dos quirópteros da Reserva Volta Velha, Itapoá, Santa Catarina, Brasil. Revista Brasileira de Zoologia, Curitiba, v. 12, p. 519-528, 1995.

STEVENS, R. D. Gradients of bat diversity in Atlantic Forest of South America: environmental seasonality, sampling effort and spatial autocorrelation. Biotropica, Malden, v. 45, p. 764-770, 2013.

STRAUBE, F. C.; BIANCONI, G. V. Sobre a grandeza e a unidade utilizada para estimar esforço de captura com utilização de redesde-neblina. Chiroptera Neotropical, Brasília, v. 8, p. 150-152, 2014.

TADDEI, V. A.; NOBILE, C. A.; MORIELLE-VERSUTE, E. Distribuição geográfica e análise morfométrica comparativa em Artibeus obscurus (Schinz, 1821) e Artibeus fimbriatus Gray, 1838 (Mammalia, Chiroptera, Phyllostomidae). Ensaios e Ciência: Ciências Biológicas, Agrárias e da Saúde, Valinhos, v. 2, n. 2, p. 71-127, 1998.

VIEIRA, T. B.; MENDES, P.; LOPES, S. R.; OPREA, M.; DITCHFIELD, A. D. Quirópteros (Mammalia, Chiroptera) do município de Alfredo Chaves, estado do Espírito Santo, Brasil. Revista Brasileira de Zoologia, Curitiba, v. 12, p. 95-102, 2010.

VIZOTTO, L. D.; TADDEI, V. A. Chave para determinação de quirópteros brasileiros. Boletim de Ciências, Faculdade de Filosofia Ciências e Letras, São José do Rio Preto, v. 1, p. 1-72, 1973.

WEBER, M. M.; TERRIBILE, L. C.; CACERES, N. C. Potential geographic distribution of Myotis ruber. Mammalia, Paris, v. 74, p. $333-338,2010$. 


\section{Appendix 1}

Bats in the region of Itabapoana drainage basin deposited in the Mammal Collection of the Federal University of Rio de Janeiro, Campus Macaé (NPM).

Anoura caudifer (NPM 187, 200, 213), Anoura geoffroyi (NPM 212), Artibeus fimbriatus (NPM 183, 196, 198, 202, 209, 214, 215), Artibeus lituratus (NPM 182, 197, 207, 1376), Artibeus obscurus (NPM 1381), Artibeus cinereus (NPM 180, 1384, 1449), Carollia perspicillata (NPM 181, 188, 190, 1382), Chiroderma doriae (NPM 1450), Chrotopterus auritus (NPM 198), Desmodus rotundus (NPM 178, 1386), Epitesicus brasiliensis (NPM 1374, 1453), Glossophaga soricina (NPM 167), Lonchorhina aurita (NPM 345, 353), Micronycteris hirsuta (NPM 50), Micronycteris microtis (NPM 1454), Micronycteris minuta (NPM 189), Molossus molossus (NPM 1209), Molossus rufus (NPM 98, 92), Myotis nigricans (NPM 185, 199, 216, 217, 1375, 1383, 1387, 1451), Myotis riparius (NPM 1448), Myotis ruber (NPM 201, 218, 219, 1452), Noctilio leporinus (NPM 1289), Platyrrhinus lineatus (NPM 195, 1455), Platyrrhinus recifinus (NPM 184, 186, 194, 208, 2011, 1377, 1378, 1379, 1380), Sturnira lilium (NPM 179, 203, 205, 1388), Trachops cirrhosus (NPM 193, 1385). 